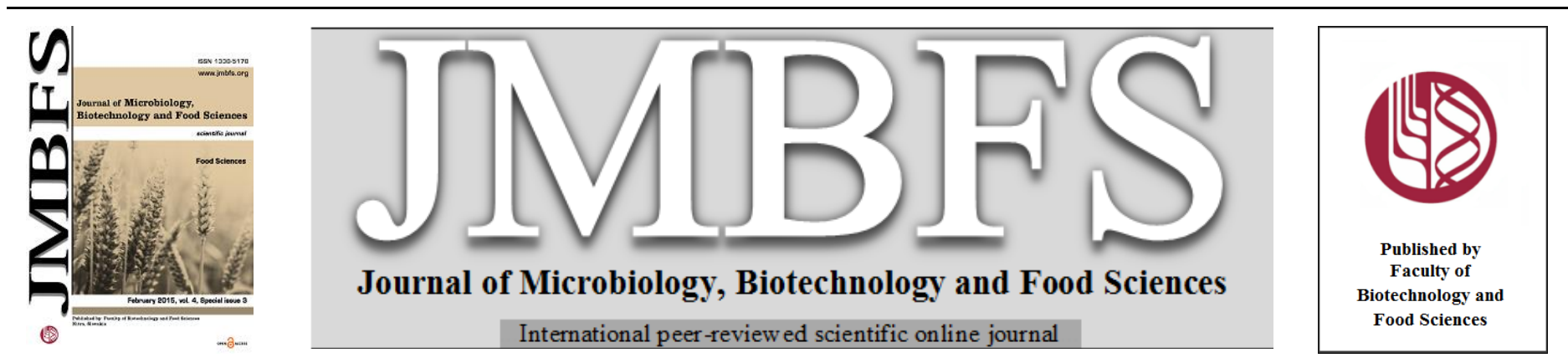

\title{
RELATIONSHIP BETWEEN MERCURY AS WELL AS CADMIUM AND ANTHOCYANIN CONTENTS IN WILD FOREST FRUITS FROM ENVIRONMENTALLY BURDEN REGION OF THE SLOVAKIA
}

\author{
Stanislav Zupkal, Alena Vollmannová ${ }^{1}$, Luboš Harangozo ${ }^{1}$, Michal Medvecký
}

Address(es): Ing. Stanislav Zupka

1 Slovak University of Agriculture, Faculty of Biotechnology and Food Sciences, Department of Chemistry, Tr. A. Hlinku 2, 94976 , Nitra, Slovakia. 2 Plant Production Research center-Grassland and Mountain Agriculture Research Institute Banská Bystrica, Krivá Research Station, Krivá 62, 02755, Krivá, Slovakia.

*Corresponding author: zupkastanislav@yahoo.com

doi: 10.15414/jmbfs.2015.4.special3.192-197

\section{ART ICLE INFO}

Received 2. 12.2014

Revised 8. 12.2014

Accepted 9. 12. 2014

Published 2. 2. 2015

Regular article

OPEN AcCESS $_{\text {ACE }}$

\begin{abstract}
Relationship bet ween total mercury as well as cadmium contents and total anthocyanins content in wild forest fruit berries collected in environemtally burden region of Stredny Spis in the Slovakia was investigated in this study. From the sampling points of different localities of this region small berries were sampled: blackberries (6 localities), blackthorns (5 localities), rosehips (6 localities), hawthorn fruits. Metal determinations were performed in a Varian AA240Z (Varian, Australia) atomic absorption spectrometer with Zeeman background correction. Total anthocyanin content (TA) in fruits was determined spectrophotometrically using the spectrophotometer (Shimadzu UV/VIS - 1240, Japan). With exception of three samples in all other fruit samples the hygienic limit for $\mathrm{Cd}(30 \mu \mathrm{g} / \mathrm{kg})$ given for foodst uffs by Slovak Republic Food Codex was exceeded. Only in one fruit sample the determined $\mathrm{Hg}$ content was higher than hygienic limit ( $30 \mu \mathrm{g} / \mathrm{kg}$ ). Total anthocyanin content expressed as $\mathrm{mg}$ cyanidin equivalents $/ \mathrm{kg}$ of fresh matter (mg $\mathrm{CE} / \mathrm{kg} \mathrm{FM}$ ) was in range 370 - 830 in blackberries (Rubus Fruticosus), 2500 - 3000 in rosehips (Rosa rubiginosa), 213 in raspberries (Prunus spinosa) and $317 \mathrm{mg} \mathrm{CE} / \mathrm{kg} \mathrm{FM}$ in hawthorn berries (Crataegus laevigata). The strong statistical dependences between investigated parameters: $\mathrm{Hg}-\mathrm{T} \mathrm{A}$ in blackthorns, $\mathrm{Cd}-\mathrm{T}$ A in raspberries, $\mathrm{Hg}-\mathrm{T}$ Ain raspberries, $\mathrm{Cd}-\mathrm{TA}$ in hawthorn and $\mathrm{Hg}-\mathrm{TA}$ in hawthorn were confirmed based on the values of correlation coefficients $(\mathrm{R}=0.6958, \mathrm{R}=0.9633, \mathrm{R}=0.9163, \mathrm{R}=0.8587$ and $\mathrm{R}=$ 0.8938 , respectively).
\end{abstract}

Keywords: Anthocyanins, mercury, cadmium, wild forest fruits

\section{INTRODUCTION}

Small fruits as raspberries, blackberries, blueberries, blackcurrants are rich in phytochemicals such as anthocyanins which are glycosidic-linked flavonoids responsible for their red, violet, purple and blue colours (Vollman nová et al., 2009). Anthocyanins are becoming increasingly important as antioxidants. During the last years anthocyanins were reported in helping to reduce the risk of coronary heart disease and prevent several chronic diseases (Wei-Dong et al., 2007). In many works a positive correlation between the intake of fruits and vegetables and prevention of diseases like atheroscelerosis, cancer, diabetes, arthritis and also ageing is documented. Total anthocyanin concentrations in wild crop are higher than in cultivated blueberries (Vollmannová et al., 2009). Metals entering the soil are predominatly in the inaccessible forms, but with the various processes occuring in the soil become available and can be received by plants (Tomáš, 2000).

High concentrations of heavy metals may affect the ecosystem and human health (Xuedong, 2012).

Anthropogenic pollution caused by heavy metals entering the plant subsequently passed into the food chain (Tomáš, 2000).

The aim of this work was to found relationship between total mercury and cadmium contents and total anthocyanins contents in wild forest fruit berries.

\section{MATERIAL AND METHODS}

The experiment was conducted in the are of central Spiš. Samples were collected in the district of Spišská Nová Ves, namely the cadastrals of villages Hrabušice, Markušovce, Matejovce nad Hornádom. Janík na Spiši a Spišská Nová Ves. The average annual temperature in this region is $6{ }^{\circ} \mathrm{C}$ and annual rainfall is $650 \mathrm{~mm}$. From the sampling points of different localities small berries were sampled, specifically blackberries (6 localities), blackthorns (5 localities), rosehips (6 localities), raspberries and hawthorn fruits. Fruit samples were collected in late Septembre 2013.

\section{Preparation of ethanolic extracts}

From manually collected berries $100 \mathrm{~g}$ samples were weighted and stored in PE bags in freezing box at temperature $-18{ }^{\circ} \mathrm{C}$. From fruit samples $50 \mathrm{~g}$ were homogenised and extracted by $100 \mathrm{ml} 80 \%$ ethanol during 12 hours. The insoluble components were removed by filtration $\left(130 \mathrm{~g} / \mathrm{m}^{2}\right.$, Filtrak, Thermalbad Wiesenbad, Germany). Before the total anthocyanins content was measured, the extracts were stored in cold at temperature $4{ }^{\circ} \mathrm{C}$.

\section{Determination of total anthocyanin content}

An aliquot $(100 \mu \mathrm{l})$ of the sample was mixed with $1 \mathrm{~cm}^{3} 0,01 \% \mathrm{HCl}$ in $80 \%$ ethanol in two test tubes. After that $2 \% \mathrm{HCl}\left(10 \mathrm{~cm}^{3}\right)$ was added to the first test tube and a buffer $\left(10 \mathrm{~cm}^{3}\right)$ with $\mathrm{pH}=3.5\left(\mathrm{c}=0.2 \mathrm{~mol} . \mathrm{dm}^{-3} \mathrm{Na}_{2} \mathrm{HPO}_{4}\right.$ with citric acid $0.1 \mathrm{~mol} . \mathrm{dm}^{-3}$ ) was added into the second test tube. The absorbance of both test tubes were measured at $520 \mathrm{~nm}$ wavelenght on the spectrophotometer (Shimadzu UV/VIS - 1240, Japan). Absorbance values were calculated to the total anthocyanin content according the equation:

$\mathrm{TA}(\mathrm{mg} / \mathrm{l})=(\mathrm{A} 1-\mathrm{A} 2) \mathrm{x} \mathrm{f}$

A1 - Absorbance of test tube with $\mathrm{HCl}$

A2 - Absorbance of test tube with buffer

$\mathrm{f}=396.598 \mathrm{mg} / \mathrm{l}$

and then expressed as $\mathrm{mg}$ of cyanidin equivalent $/ \mathrm{kg}$ of fresh matter $(\mathrm{CE} / \mathrm{kg}$ FM). 
Determination of the total content of risk metals $(\mathrm{Hg}, \mathrm{Cd})$

Homogenized berry samples ( $1 \mathrm{~g}$ ) were mineralized in a closed system of microwave digestion using Mars X-Press 5 (CEM Corp., USA) in a mix ture of $5 \mathrm{~mL} \mathrm{HNO}_{3}$ (Suprapur, Merc, Germany) and $5 \mathrm{~mL}$ deionized water $(0.054$ $\mu \mathrm{S} / \mathrm{cm}$ ) from Simplicity 185 (Millipore, UK). Metal determinations were performed in a Varian AA240Z (Varian, Australia) atomic absorption spectrometer with Zeeman background correction. The graphite furnace technique was used for the determination of $\mathrm{Cd}$. The total $\mathrm{Hg}$ content was determined using equipment AMA 254 (Altec, ČR). The obtained results were expressed as $\mu \mathrm{g} / \mathrm{kg}$ FM. Each analysis was done in 6 repetitions.

\section{RESULTS AND DISCUSSION}

\section{Determination of total anthocyanins content}

In Table 1 the total anthocyanin content (TA) in investigated fruit species is presented. Total anthocyanin content expressed as $\mathrm{mg} \mathrm{CE} / \mathrm{kg} \mathrm{FM}$ was in range 370 - 830 in blackberries (Rubus Fruticosus), 2500 - 3000 in rosehips (Rosa rubiginosa), 213 in raspberries (Prunus spinosa) and $317 \mathrm{mg} \mathrm{CE} / \mathrm{kg} \mathrm{FM} \mathrm{in}$ hawthorn berries (Crataegus laevigata). The highest content found in rose hips is $4-6$ time and $10-15$ times higher than that in blackberries and raspberries, respectively.

Table 1 Total anthocy anins (TA) content in investigated fruit samples from different localities ( $\mathrm{mg}$ $\mathrm{CE} / \mathrm{kg} \mathrm{FM})$

\begin{tabular}{|c|c|c|c|}
\hline & Sample & $\begin{array}{c}\text { Total anthocyanins content } \\
(\mathrm{mg} \mathrm{CE} / \mathrm{kg} \mathrm{FM})\end{array}$ & SD \\
\hline \multirow{6}{*}{ Blackberries } & Blackberry 1 & $553.46 \mathrm{~b}$ & 26.498 \\
\hline & Blackberry 2 & $652.6233 \mathrm{c}$ & 26.982 \\
\hline & Blackberry 3 & $405.0267 \mathrm{a}$ & 59.190 \\
\hline & Blackberry 4 & $563.3633 \mathrm{~b}$ & 24.173 \\
\hline & Blackberry 5 & $644.9617 \mathrm{c}$ & 46.741 \\
\hline & Blackberry 6 & $830.21 \mathrm{~d}$ & 24.757 \\
\hline \multirow{5}{*}{ Blackthorns } & Blackthorn 1 & $445.765 \mathrm{~b}$ & 33.809 \\
\hline & Blackthorn 2 & $369.94 \mathrm{a}$ & 35.734 \\
\hline & Blackthorn 3 & $464.02 \mathrm{~b}$ & 46.436 \\
\hline & Blackthorn 4 & $541.875 \mathrm{c}$ & 43.070 \\
\hline & Blackthorn 5 & $467.125 \mathrm{~b}$ & 35.006 \\
\hline \multirow{6}{*}{ Rosehips } & Rosehip 1 & $2930.373 \mathrm{c}$ & 92.364 \\
\hline & Rosehip 2 & $2737.845 \mathrm{~b}$ & 38.487 \\
\hline & Rosehip 3 & $2678.357 \mathrm{~b}$ & 66.386 \\
\hline & Rosehip 4 & $2675.713 \mathrm{~b}$ & 30.868 \\
\hline & Rosehip 5 & $2693.558 \mathrm{~b}$ & 35.089 \\
\hline & Rosehip 6 & $2575.337 \mathrm{a}$ & 68.577 \\
\hline Raspberry & Raspberry & 213.025 & 24.357 \\
\hline Hawthorn & Hawthorn & 317.3683 & 46.443 \\
\hline
\end{tabular}

Only in T A content in blackberries the influence of locality of sample collection was confirmed $(\mathrm{p}<0.05)$.

Table 2 Average total anthocyanin (TA) content in different fruit species (mg CE/kg FM)

\begin{tabular}{lc}
\hline & $\begin{array}{c}\text { Average (mg } \\
\text { CE/kg FM) }\end{array}$ \\
\hline Raspberries & $213.025 \mathrm{a}$ \\
\hline Hawthorn & $317.368 \mathrm{a}$ \\
\hline Blackthorns & $457.745 \mathrm{~b}$ \\
\hline Blackberries & $608.274 \mathrm{c}$ \\
\hline \multicolumn{2}{c}{ Rosehips } \\
\hline $\begin{array}{l}\text { Values marked with the same letter are not } \\
\text { significantly different }(\mathrm{p}<0.05)\end{array}$
\end{tabular}

Only between raspberries and hawthorn there are not statistically significant differences in T A content (Table 2.). The determined T A content in the other fruit species are statistically significant different $(p<0.05)$. Our values of TA content determination are lower than those presented by Moyer et al. (2002), who in blackberries determined $890-2110(\mathrm{mg} \mathrm{CE} / \mathrm{kg} \mathrm{FM})$. On the other hand Pantelidis et al. (2007) determined lower TA content in raspberries (from 1.3 up to $49.1 \mathrm{mg}$ cyanidin-3-glucoside equivalents $100 \mathrm{~g}^{-1}$ fresh weight) and in blackberries (125 - $152 \mathrm{mg}$ cyanidin-3-glucoside equivalents $100 \mathrm{~g}^{-1}$ fresh weight).

\section{Determination of the heavy metal content}

The results of total mercury and cadmium contents are shown in Table 2. Total content of mercury was in range $0.3-6.0 \mu \mathrm{g} / \mathrm{kg}$ calculated to the fresh sample except one sample (Rosehip 1 ) which has 15 -fold higher mercury content than other samples. Also in this sample was exceeded the limit $30.0 \mu \mathrm{g} / \mathrm{kg}$ of $\mathrm{Hg}$ in foodstuffs given by Slovak Republic Food Codex, part II, title 10, Annex. 2 „Maximum contaminant content in food valid in the Slovak Republic" (Decree of the Ministry of Agriculture and Ministry of Health č.608 / 3 / 2004-100 of 15 March 2004 as amended by Decree no. 1907/2004 - 100 of 21 July 2004 and 
Decree. 3372/ 2004-100 of 17 January 2005). Total Cd contents in samples were in range 17 - $93 \mu \mathrm{g} / \mathrm{kg}$ of Cd including one sample (Rosehip 3) which had 387.7 $\mu \mathrm{g} / \mathrm{kg}$ of cadmium, calculated to fresh sample. All samples except three samples
(Blackberry 2, Rosehip 5 and Raspberry) exceeded the $30 \mu \mathrm{g} / \mathrm{kg}$ of Cd limit for foodstuffs given by Slovak Republic Food Codex (described before). Rosehip 3 sample exceeded this limit almost four times.

Table 3 Content of $\mathrm{Hg}$ and $\mathrm{Cd}$ in investigated fruit samples from different localities $(\mathrm{mg} / \mathrm{kg} \mathrm{FM})$

\begin{tabular}{|c|c|c|c|}
\hline & Sample & $\begin{array}{l}\mathrm{Hg} \text { content } \\
(\mu \mathrm{g} / \mathrm{kg} \mathrm{FM})\end{array}$ & $\begin{array}{l}\text { Cd content } \\
(\mu \mathrm{g} / \mathrm{kg} \text { FM) }\end{array}$ \\
\hline \multirow{6}{*}{ Blackberries } & Blackberry 1 & $2.046 \mathrm{a}$ & $46.258 \mathrm{bc} *$ \\
\hline & Blackberry 2 & $2.401 \mathrm{a}$ & $28.433 \mathrm{a}$ \\
\hline & Blackberry 3 & $2.012 \mathrm{a}$ & $50.126 \mathrm{c} *$ \\
\hline & Blackberry 4 & $1.592 \mathrm{a}$ & $43.663 \mathrm{~b}^{*}$ \\
\hline & Blackberry 5 & $1.453 \mathrm{a}$ & $47.682 b^{*}$ \\
\hline & Blackberry 6 & $0.779 \mathrm{a}$ & $31.358 \mathrm{a} *$ \\
\hline \multirow{5}{*}{ Blackthorns } & Blackthorn 1 & $1.655 \mathrm{c}$ & $42.996 \mathrm{a} *$ \\
\hline & Blackthorn 2 & $1.384 \mathrm{~b}$ & $37.699 \mathrm{a}^{*}$ \\
\hline & Blackthorn 3 & $1.223 \mathrm{a}$ & $32.102 \mathrm{a} *$ \\
\hline & Blackthorn 4 & $2.038 \mathrm{~d}$ & $37.495 \mathrm{a} *$ \\
\hline & Blackthorn 5 & $1.491 \mathrm{~b}$ & $52.43 b^{*}$ \\
\hline \multirow{6}{*}{ Rosehips } & Rosehip 1 & $30.612 \mathrm{e}^{*}$ & $49.24 b^{*}$ \\
\hline & Rosehip 2 & $5.351 \mathrm{~d}$ & $59.946 c^{*}$ \\
\hline & Rosehip 3 & $1.481 \mathrm{~b}$ & $387.705 \mathrm{f}^{*}$ \\
\hline & Rosehip 4 & $0.349 \mathrm{a}$ & $93.281 \mathrm{e}^{*}$ \\
\hline & Rosehip 5 & $3.91 \mathrm{c}$ & $17.87 \mathrm{a}$ \\
\hline & Rosehip 6 & $5.076 \mathrm{~d}$ & $78.981 \mathrm{~d}^{*}$ \\
\hline Raspberry & Raspberry & 6.433 & 16.222 \\
\hline Hawthorn & Hawthorn & 1.046 & $80.095^{*}$ \\
\hline \multicolumn{4}{|c|}{$\begin{array}{l}\text { *- exceeded limit } 30 \mu \mathrm{g} / \mathrm{kg} \text { FM for Cd, } 30 \mu \mathrm{g} / \mathrm{kg} \text { FM for Hg given by Slovak Republic Food } \\
\text { Codex, part II, title } 10 \text {, Annex. } 2 \text { „Maximum contaminant content in food valid in the Slovak } \\
\text { Republic" (Decree of the Ministry of Agriculture and Ministry of Health č.608/3/2004-100 o } \\
15 \text { March } 2004 \text { as amended by Decree no. } 1907 / 2004-100 \text { of } 21 \text { July } 2004 \text { and Decree. } 3372 / \\
2004-100 \text { of } 17 \text { January 2005). }\end{array}$} \\
\hline
\end{tabular}

Table 4 Average values of $\mathrm{Hg}$ and $\mathrm{Cd}$ contents in different fruit species $(\mu \mathrm{g} / \mathrm{kg} \mathrm{FM})$

\begin{tabular}{lll}
\hline & $\begin{array}{l}\text { Hg content } \\
(\mu \mathrm{g} / \mathrm{kg} \text { FM })\end{array}$ & $\begin{array}{l}\text { Cd content } \\
(\mu \mathrm{\mu g} / \mathbf{k g} \text { FM })\end{array}$ \\
\hline Blackberries & $11.357 \mathrm{a}$ & $41.253 \mathrm{a}$ \\
\hline Blackthorns & $1.558 \mathrm{a}$ & $62.963 \mathrm{a}$ \\
\hline Rosehips & $7.796 \mathrm{a}$ & $114.504 \mathrm{~b}$ \\
\hline Raspberries & $6.433 \mathrm{a}$ & $16.222 \mathrm{a}$ \\
\hline
\end{tabular}

\begin{tabular}{lll}
\hline Hawthorn & $1.046 \mathrm{a}$ & $80.095 \mathrm{ab}$
\end{tabular}

Our results confirmed the negative influence of rezidual environmental pollution due human industrial activity in the past in the observed region Stredny Spis. The determined values of $C d$ content in raspberries was 0.016 and in rosehips 0.114 $\mathrm{mg} / \mathrm{kgFM}$, which is almost 2-times and 4-times higher (respectively) than that determined by Figurska et al. (2010). Our results correspond to those presented by Wieczorek et al. (2010) who determined in wild berries (blackberry, raspberry, blueberry) 6 to $49 \mu \mathrm{g} \mathrm{Cd} / \mathrm{kg} \mathrm{FM}$. 


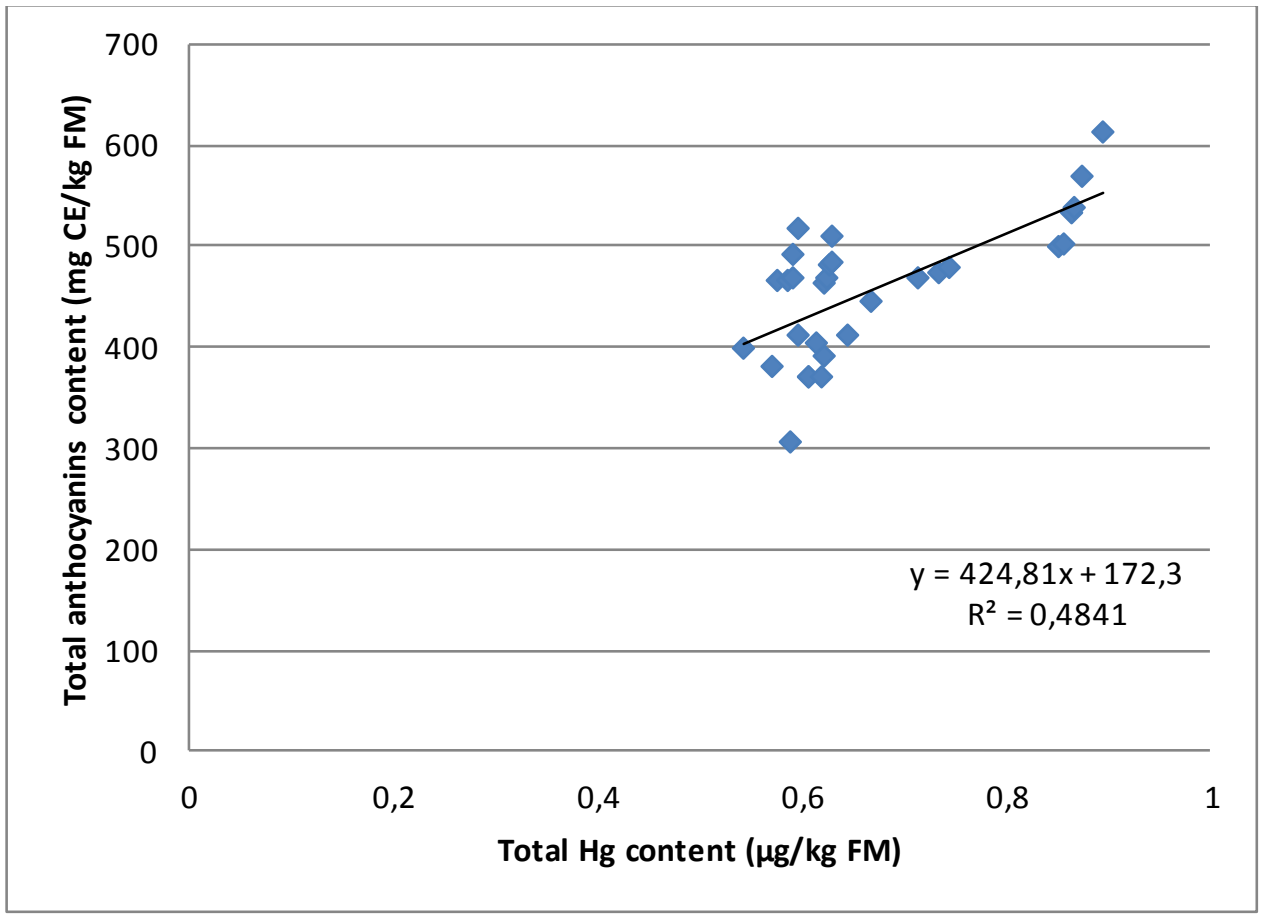

Figure 1 Correlation relationship between determined $\mathrm{Hg}$ and $\mathrm{T} \mathrm{A}$ content in fruits of black thorn

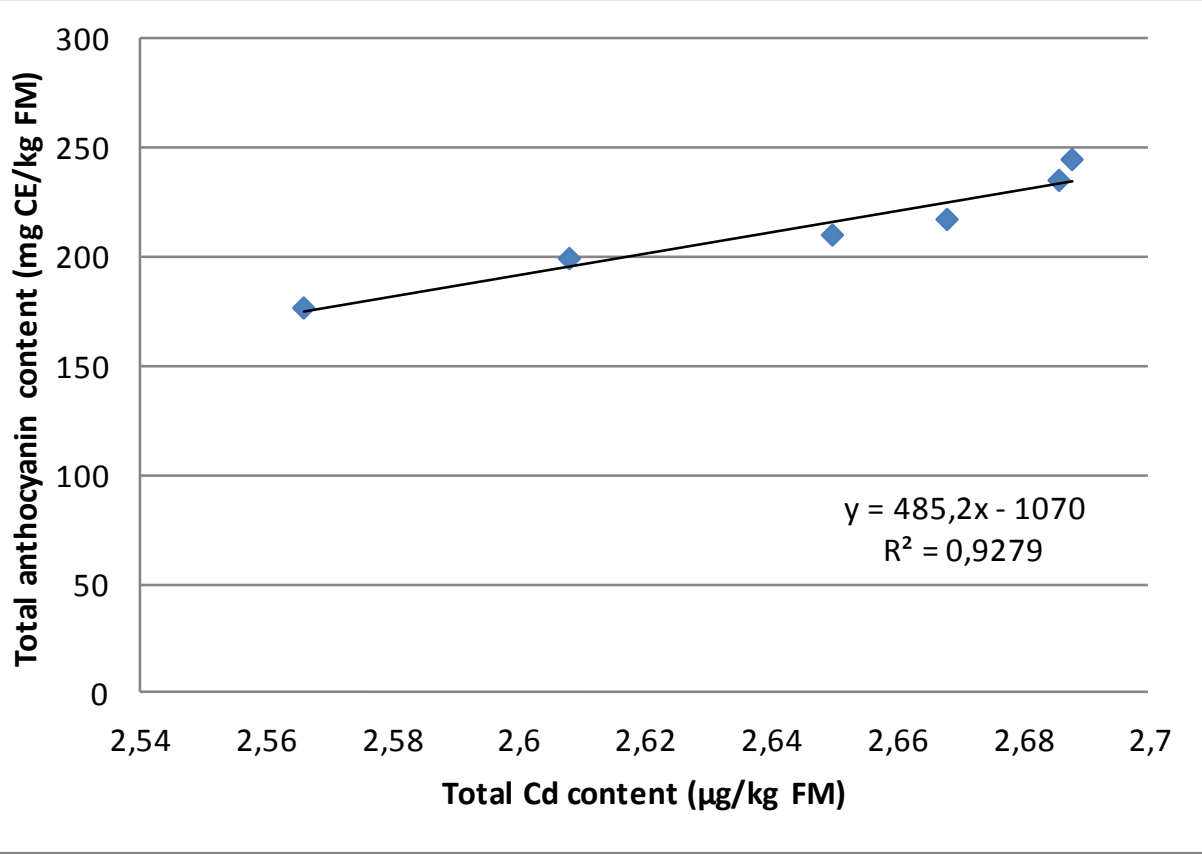

Figure 2 Correlation relationship between determined $\mathrm{Cd}$ and T A content in fruits of raspberry 


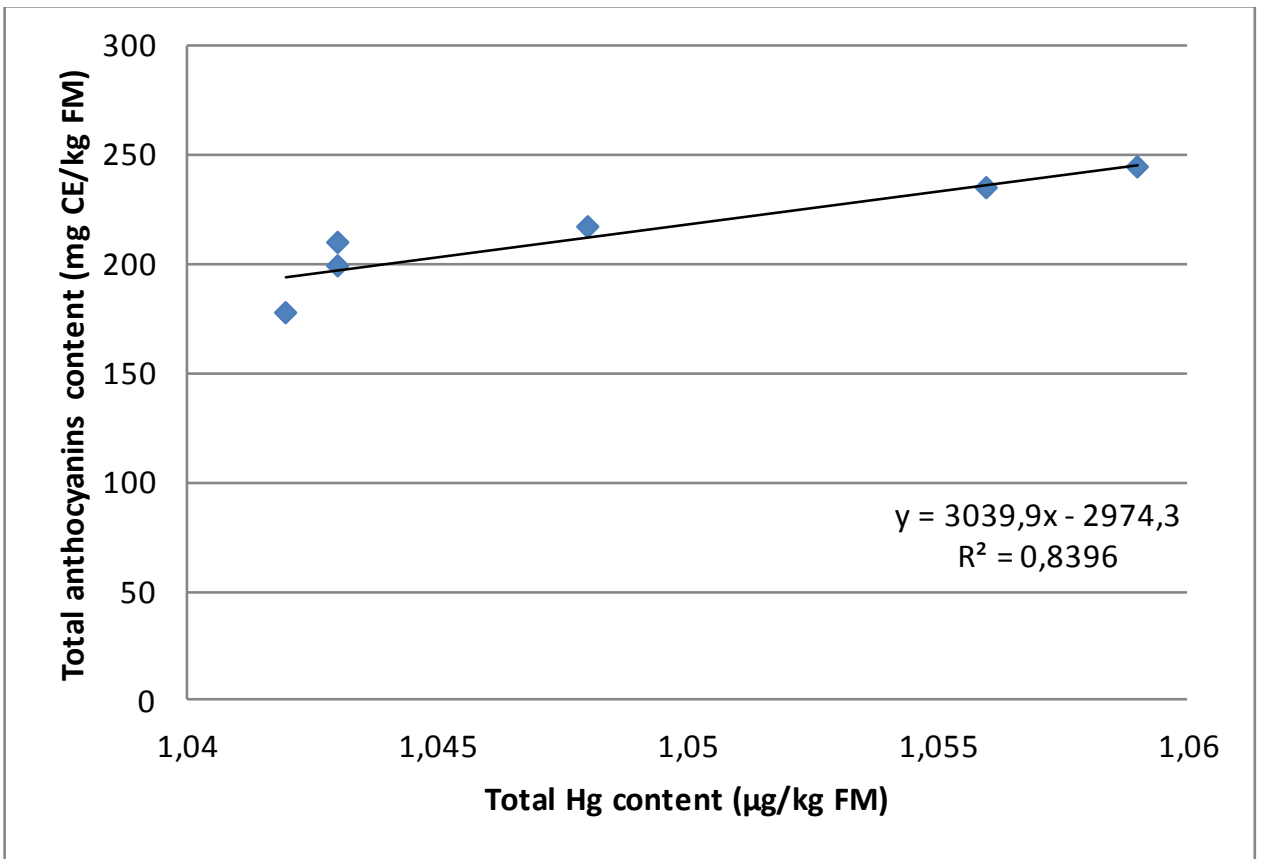

Figure 3 Correlation relationship between determined $\mathrm{Hg}$ and $\mathrm{T} \mathrm{A}$ content in fruits of raspberry

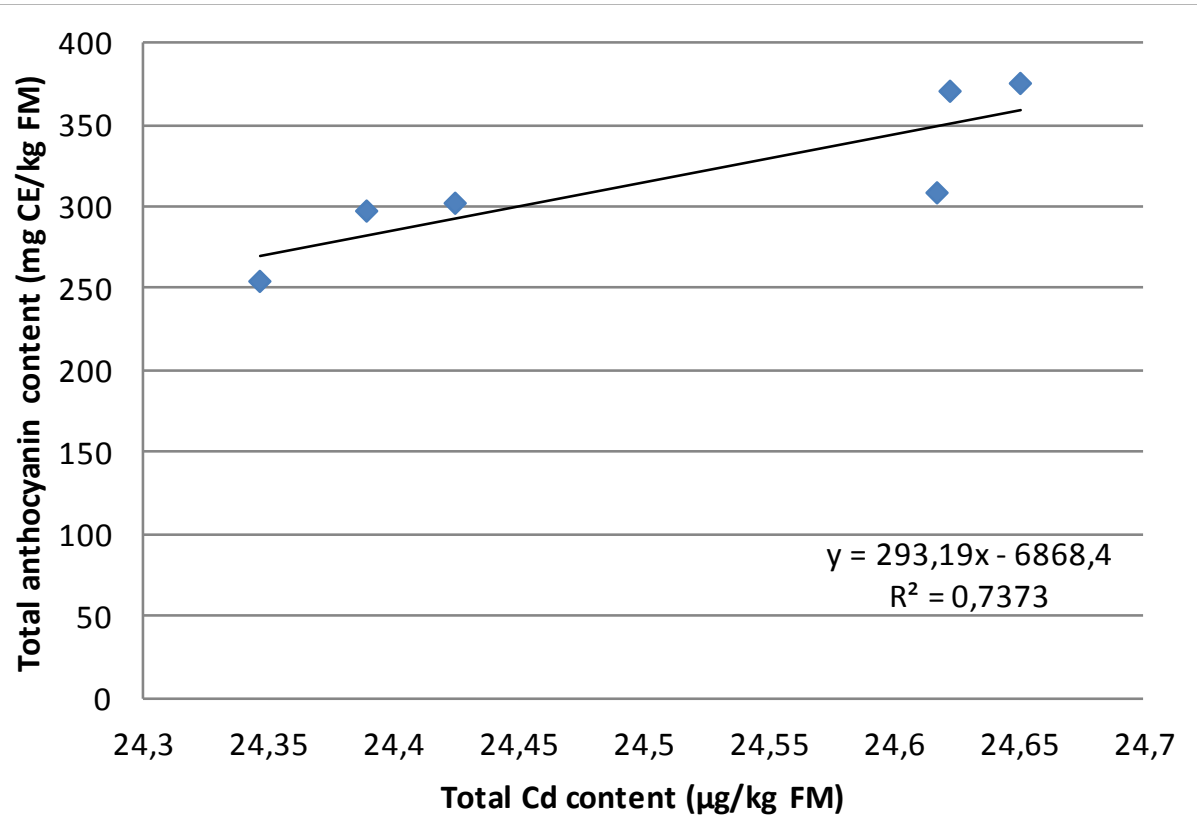

Figure 4 Correlation relationship between determined $\mathrm{Cd}$ and $\mathrm{T} \mathrm{A}$ content in fruits of hawthorn 


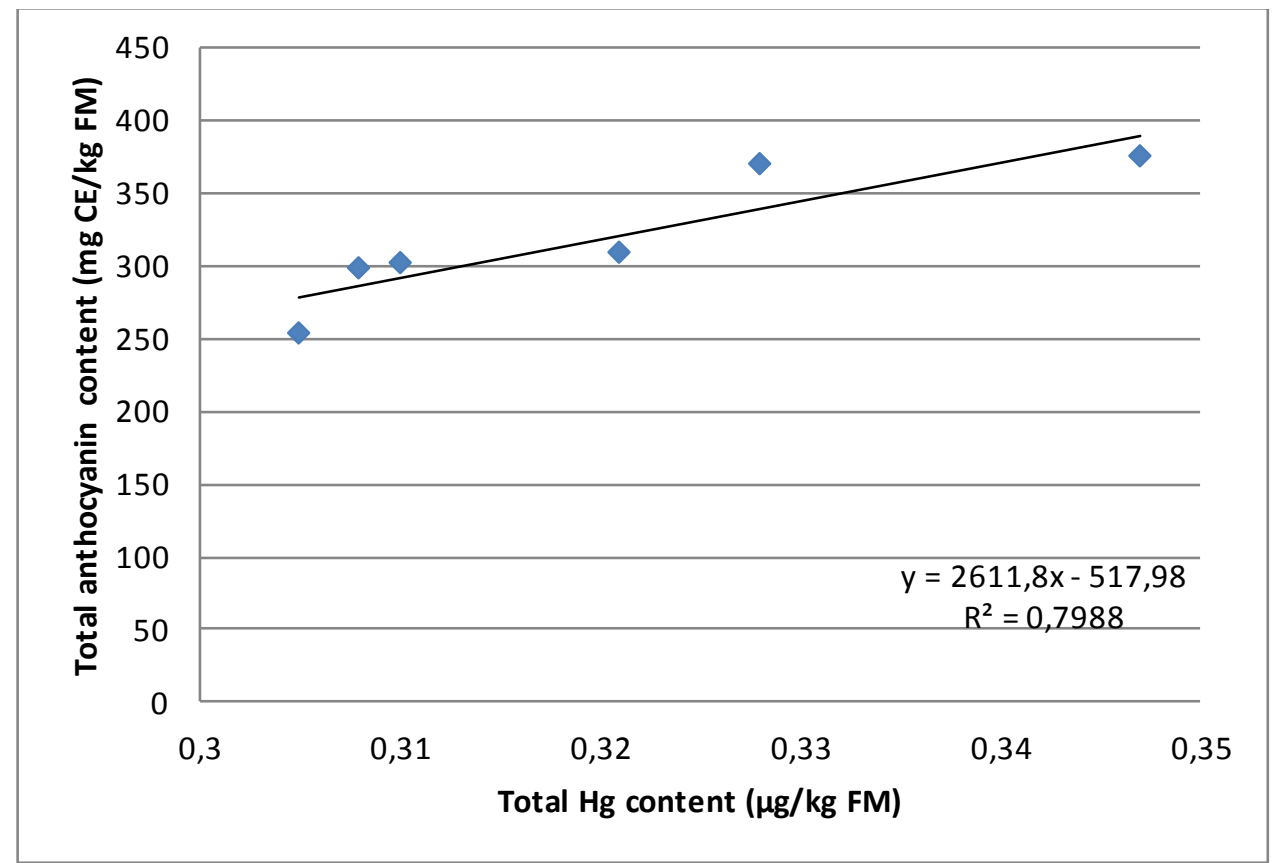

Figure 5 Correlation relationship between determined $\mathrm{Hg}$ and $\mathrm{T}$ A content in fruits of hawthorn

The strong statistical dependences bet ween investigated parameters: $\mathrm{Hg}-\mathrm{T} \mathrm{A}$ in blackthorns, , $\mathrm{Cd}-\mathrm{TA}$ in raspberries, $\mathrm{Hg}-\mathrm{TA}$ in raspberries, $\mathrm{Cd}-\mathrm{TA}$ in hawthorn and $\mathrm{Hg}-\mathrm{TA}$ in hawthorn were confirmed based on the values of correlation coefficients $(\mathrm{R}=0.6958, \mathrm{R}=0.9633, \mathrm{R}=0.9163, \mathrm{R}=0.8587$ and $\mathrm{R}=$ 0.8938 , respectively).

\section{CONCLUSION}

Blackberries, blackthorns, rosehips, raspberries and hawthorn are an excellent source of bioactive compounds with the significant benefit on the human health. Compared to hygienic limits given by legislation in the Slovak Republic these fruit species are in terms of Cd risky because of enhanced Cd amount determined in all investigated fruit samples. The regular consumption of the fruit from Stredny Spis region could be hazardous for the human health because of $\mathrm{Cd}$ toxicity for living organisms. On the other hand the determined $\mathrm{Hg}$ content in the investigated fruit species did not pose a risk for the human health. It is necessary to monitor the content of hazardous heavy metals in all consumed fruit species collected especially in regions with rezidual or actual environmental contamination.

Acknowledgments: This work was co-funded by European Community under project No. 26220220180: Building Research Centre "AgroBioTech" and also supported by project: VEGA 1/0308/14.

\section{REFERENCES}

FIGURSKA-CIURA, Danuta - BRONKOWSKA, Monika - ORZEL, DagmaraSTYCZYŃSKA, Marzena - WYKA, Joanna - LOŹNA, Karolina - JADWIGA, Biernat - ZECHALKO-CZAJKOWSKA, Alicja. 2010. Cadmium Content in Plant Products Cultivated Near a Copperworks. In Polish journal of environmental studies, vol. 19, no. 6, p $1383-1390$.

MOYER, Richard - HUMMER, Kim - FINN, Chad - FREI, Balz WROLST AD, Ronald. 2002. Anthocyanins, Phenolics, and Antioxidant Capacity in Diverse Small Fruits: Vaccinium, Rubus, and Ribes. In Journal of agricultural and food chemistry, vol. 50, no. 3, p $519-525$.

http://dx.doi.org/10.1021/jf011062r

PANTELIDIS, G.E. - VASILAKAKIS, M. - MANGANARIS, G.A. DIAMANTIDIS, G. 2007. Antioxidant capacity, phenol, anthocyanin and ascorbic acid contents in raspberries, blackberries, red currants, gooseberries and Cornelian cherries. In Food Chemistry, vol.102, no. 3, p 777 - 783. http://dx.doi.org/10.1016/j.foodchem.2006.06.021

TOMÁŠ, J. et al. 2000. Hodnotenie bioprístupnosti kadmia, medi, zinku a chrómu v sfére kontaminovanej fluvizeme, In Acta fytotechnica et zootechnical. SPU Nitra, 2000, s. 25 - 28.

VOLLMANNOVÁ, Alena - TÓTH, Tomáš - URMINSKÁ, Dana POLÁKOVÁ, Zuzana - T IMORACKÁ, Mária - MARGITANOVÁ, Eva. 2009. Anthocyanins Content in Blueberries (Vaccinium corymbosum L.) in Relation to Freezing Duration. In Czech journal of food sciences, vol. 27, p $204-206$, ISSN 1805-9317.

WIECZOREK, J. - PIETRZAK, M. - OSOWSKI, A. - WIECZOREK, Z. 2010 Determination of lead, cadmium, and persistent organic organic pollutants in wild and orchard-farm-grown fruit in northeastern Poland. In Journal of toxicology and environmental health, vol. 73, no. 17-18, p. $1236-1243$. http://dx.doi.org/10.1080/15287394.2010.492009

WANG, Wei-Dong - XU, Shi-Ying. 2007. Degradation kinetics of anthocyanins in blackberry juice and concentrate. In Journal of Food Engineering, vol. 82, no. 3 , p $271-275$.

http://dx.doi.org/10.1016/j.jfoodeng.2007.01.018

XUEDONG, Yan - ZHANG, Fan - YAO, Tandong. 2012. Relationship bet ween Heavy Metal Concentrations in Soils and Grasses of Roadside Farmland in Nepal. In International journal of environmental research and public health, vol. 9, no. 9, p 3029 - 3226 . http://dx.doi.org/10.3390/ijerph9093209 